\title{
Financial Environmental Disclosure in the Annual Reports of Listed Companies in Poland
}

\author{
Justyna Dyduch
}

\begin{abstract}
This article aims to analyse the extent and quality of financial environmental disclosure in annual reports of companies listed on the Warsaw Stock Exchange and representing thirteen sectors significantly affecting the environment. The study used a content analysis of annual reports produced by 148 companies for 2015 . About $60 \%$ of companies disclose financial environmental information. The average level of disclosure can be assessed as low. There has been noticed a diversity of industrial sectors in terms of the number of disclosing enterprises and the extent and quality of the disclosure. The companies usually presented information regarding investment expenditure for environmental protection. There was a positive, but moderate dependence between the level of disclosure and total assets and the lack of impact of profitability, presence of dominant share of foreign capital and period of listing of the company on the stock exchange on the level of disclosure.
\end{abstract}

Index Terms-Annual report, Content analysis, financial environmental disclosure, Warsaw stock exchange.

\section{INTRODUCTION}

Economic activity is inextricably linked to the negative impact on the natural environment. The authorities responsible for the state of environmental quality, in order to reduce the impact, apply different instruments of environmental policy: legal and administrative means, such as emission standards, bans, administrative permits, as well as economic means in the form of taxes and environmental charges, transferable allowances to emit air pollutants and environmental subsidies. In addition to pressure from the public authorities, the operation of enterprises in protecting the natural environment is also influenced by the concept of corporate social responsibility (CSR) gaining increasing importance in the modern market economy.

The impact of specific industries or individual companies on the environment and the influence of their ecological performance on their financial situation are a concern of different stakeholders, such as investors, public authorities and environmental organizations, which is reflected in a growing interest in disclosure, by the companies, of environmental information in annual reports, CSR reports or in other documents. This trend can also be seen in relation to the Polish enterprises.

In Poland, the consistent environmental policy conducted by the state since the early $90 \mathrm{~s}$, based, in particular, on the use

Manuscript received March 14, 2017; revised June 7, 2017.

Justyna Dyduch is with the Department of Economics, Finance and Environmental Management, Faculty of Management, AGH University of Science and Technology, Cracow, Poland (e-mail: jdyduch@zarz.agh.edu.pl). of environmental charges and administrative permits, as well as financial support for environmental investments of firms has resulted in a significant reduction of the harmful impact of industry on the environment. The effect of Polish accession to the European Union in 2004 was a further tightening of environmental regulations for companies and there was a need for them to realise costly investments in order to comply with EU environmental standards. An issue of special concern and interest of public authorities, the media and other parties in the context of compliance with EU regulations, in Poland, is the energy sector due to dominant share of fossil fuels (mainly coal and lignite) in the structure of fuels used to produce energy. Another factor significantly influencing the companies' activities in the field of environmental protection and their financial situation (not only in the energy sector) is the European Union Emissions Trading System introduced in 2005.

This paper aims to analyse the extent and quality of financial environmental disclosure in annual reports of companies in Poland, representing thirteen sectors significantly affecting the environment.

\section{LITERATURE REVIEW}

Corporate social responsibility disclosure is the subject of numerous studies conducted on the basis of various theories, including the stakeholder theory, legitimacy theory, institutional theory and the voluntary disclosure theory. They are used to explain the factors influencing the information policy on CSR.

According to the stakeholder theory, the company should have regard to meeting the needs of not only its shareholders, but also to take into account the interests of all other parties (stakeholders), which may influence the achievement of their objectives or are influenced by its impact [1].

The legitimacy theory assumes that external stakeholders expect the company to always take such actions that will allow them to perceive its operation as compliant with the law and socially acceptable. This theory considers "how the adoption of a specific strategy regarding disclosure of information can enable to obtain, maintain or regain social acceptance for an action" [2]. The institutional theory applies to the forms taken by organizations and tries to explain why organizations are becoming more homogeneous and what specific forms of organization can be taken to achieve social acceptance [2].

The voluntary disclosure theory assumes that companies are willing to disclose 'good' news and hide 'bad' news [3]. Sometimes, these different research perspectives may lead to conflicting assumptions about the impact of certain factors on the level of CSR disclosure. The relationship between CSR 
performance and CSR disclosure may serve as an example. According to the legitimacy theory, there is expected a negative correlation between the variables, and the voluntary disclosure theory indicates a positive correlation [4].

Environmental disclosure of companies are analysed as one of the areas of CSR disclosure or as a separate subject of study. In the latter case, as examples of research on the extent and quality of environmental reporting practices in developed countries, there can be indicated publications such as [5]-[10]. A research in this field is has also been carried out for developing countries [11]-[14].

The subject of the analyses is financial [15], [16], non-financial [17], [18] or both types of environmental disclosure [3], [6], [19]. Firms usually have less discretion in disclosing financial environmental information since such disclosures are also subject to the applicable financial reporting principles [3].

According to a study by Bewley and Li [3] concerning environmental disclosure in annual reports of Canadian production companies for 1993, only 30 of the 188 analysed companies revealed financial information, and $70-$ both financial and non-financial information.

More recent study [11] carried out on a sample of 223 Turkish listed companies has shown that about half of them make environmental disclosure in annual reports. An analysis of the disclosures made by textile companies in Bangladesh [12] revealed that only 9 of the 29 companies puts any environmental information in the annual report. Also, a study of Italian listed companies indicate a low level of disclosure of environmental information [7]. It should be emphasized that there is a tendency of increasing the number of companies making environmental disclosure and improving the quality of the disclosure over time [10], [13], [19], [20].

An important area of research on corporate environmental disclosure are determinants of the information policy of companies. The factors related to the characteristics of companies that are often studied as potential determinants of the level of environmental disclosure include industry sector classification, firm size and profitability.

Industry sector classification is examined primarily in the context of a potential impact on the environment of individual sectors. Companies from sectors with a greater environmental impact may be more willing to disclose more information "in order to avoid adverse actions by uninformed stakeholders against the worst polluters in the industry" [3]. The research usually confirms a usually higher level of disclosure in sectors with a high environmental impact (e.g. energy, mining, chemical industry) in comparison with other sectors [3], [19], but, e.g. in [11], there can be found opposite conclusions.

A positive relationship between the firm size and the level of environmental disclosures has been found by many studies [20]-[22]. A higher level of disclosure of large enterprises is explained that they have greater political visibility and must meet higher expectations of environmental stakeholders than small companies, therefore an environmental disclosure can help to improve their reputation and to reduce the political costs [3], [19].

The results of studies on the impact of profitability of a company on the quantity and quality of disclosure of environmental information are contradictory. Some studies show a positive relationship between these variables [23], and the other that there is no such correlation [3].

The other factors which have been studied in the context of impact on the level of environmental disclosure include: foreign ownership, quotation on the stock market, environmental certification [20], ownership diffusion, financial leverage, political pressure [6], outsiders' knowledge of environmental exposure, audit quality [3] or firm age, foreign listing status [21].

A research on Polish companies relate primarily to CSR disclosure [24]-[27]; sometimes, they also focus only on environmental disclosure [28]-[30]. The vast majority of publications is devoted to the disclosure of non-financial information. To the best of the author's knowledge, there has not been carried out a research on the extent and quality of financial environmental disclosure in annual reports on a large sample of listed companies in Poland.

\section{RESEARCH METHODOLOGY}

The study included all companies listed on the Warsaw Stock Exchange (WSE) as of August 25, 2016, with legal addresses in Poland and classified in one of the thirteen sectors, characterized by exerting a significant impact on the natural environment, i.e. energy and industrial sectors (cf. Table I). There have been taken into account a total of 148 companies.

TABLE I: THE SAMPLE OF ENTERPRISES

\begin{tabular}{|c|c|c|}
\hline Sector & $\begin{array}{l}\text { Number of } \\
\text { companies }\end{array}$ & $\begin{array}{l}\text { Percentage of } \\
\text { the sample }\end{array}$ \\
\hline Energy & 8 & 5.41 \\
\hline $\begin{array}{l}\text { Raw material and petroleum } \\
\text { industry }\end{array}$ & 7 & 4.73 \\
\hline Chemical industry & 9 & 6.08 \\
\hline Metal industry & 20 & 13.51 \\
\hline Electromechanical industry & 29 & 19.59 \\
\hline Plastics industry & 8 & 5.41 \\
\hline Construction materials industry & 16 & 10.81 \\
\hline Light industry & 6 & 4.05 \\
\hline Pharmaceutical industry & 11 & 7.43 \\
\hline Automotive industry & 5 & 3.38 \\
\hline Wood industry & 7 & 4.73 \\
\hline Food industry & 17 & 11.49 \\
\hline Other & 5 & 3.38 \\
\hline Total & 148 & 100.00 \\
\hline
\end{tabular}

Source: own elaboration.

There have been analysed the annual reports of these companies prepared for 2015, available on their websites or on the website of WSE. An annual report contains a letter of Chairman of the Board, financial statements, the opinion and report of an expert auditor, a Management Board report on the activity and a statement of the Board. In the vast majority of the analysed annual reports, financial statements have been prepared in accordance with International Financial Reporting Standards (IFRS) and included:

1) A statement of financial position (balance sheet equivalent). 
2) A statement of profit or loss and other comprehensive income.

3) A statement of cash flows.

4) A statement of changes in equity.

5) Additional notes to the financial statements.

Only in the reports of individual companies, not constituting a capital group, financial statements have been presented in the form set out in the Polish Accounting Act, which includes a balance sheet, income statement, cash flow statement, statement of changes in equity and additional notes.

To assess the extent and quality of the financial environmental disclosure, there has been used a content analysis, which is very often used in studies on the corporate social responsibility disclosure, including by Clarkson, Li, Richardson, and Vasvari [5], Gamerschlag, Möller, and Verbeeten [23], Hughes, Anderson, and Golden [31], and Krasodomska [32]. The content analysis is to identify ex ante the list of information regarding the area of research and then assessing the disclosure of the information in the document (e.g. report) using a points system (disclosure index).

The study has analysed the following types of financial environmental information:

1) Investment expenditure on projects to protect the environment.

2) Ecological charges (i.e. the fees for emissions of dust and gas, water consumption, entry of waste water, waste discharge and disposal, product charges).

3) Cost of allowances for greenhouse gas emissions (associated with the operation of the European Union Emissions Trading System),

4) Environmental fines, damages, restoration costs,

5) Other operating costs of environmental protection (e.g., the air pollution abatement equipment depreciation, remuneration of environmental services, operating costs of the air pollution abatement equipment, the cost of certification),

6) Environmental liabilities (credits and loans for the implementation of environmental investments),

7) Provisions for environmental protection costs,

8) Subsidies for environmental investments,

9) Environmental revenues (e.g. sale of the allowances for emissions of greenhouse gas or gypsum as a by-product of the flue-gas desulphurisation),

10) Environmental savings (eg. use of recycled materials).

The measure of the extent and quality of financial environmental disclosure in particular annual reports have been a disclosure index calculated in such a way that for each of the above-mentioned ten kinds of information, there have been awarded points, then the total points assigned to a given report was divided by 30 . It has been used the following score system:

1) 0 points - if there is no disclosure.

2) 1 point -if the presence of a particular environmental issue (e.g. investment expenditure) is only mentioned, without giving a monetary value,

3) 2 points - if the environmental issue is quantified in monetary values at the aggregate level (e.g. there is given the amount of the total investment expenditure, without specifying the exact sum of spending on environmental projects),

4) 3 points - if the environmental issue is separately quantified in monetary values.

The value of the index has been expressed in percentage and can range from $0 \%$ to $100 \%$. The higher the index value, the higher the level of financial environmental disclosure.

The subject of estimation has involved the disclosure of a given environmental piece of information in the annual report, not the presence or absence of the event in the company. For example, a piece of information that the environmental investment expenditure are 0.5 million has been assessed in the same way as a clear statement that these expenses were not incurred in the year (they are equal to 0 ).

There has also been used a Pearson's correlation coefficient to assess a relationship between financial environmental disclosure and the size of companies (expressed by total assets), profitability (expressed by the return on assets - ROA), the duration of the period of listing of the companies on the stock market (in months of listing on the stock exchange by the end of 2015) and dominant share of foreign capital in the share capital of the companies. The last variable has been equal to 1 if there is a strategic foreign investor, or 0 otherwise.

\section{REsUlts}

Financial environmental information have been disclosed by the surveyed companies in additional notes to the financial statements and/or the Management Board report on the activity.

The templates of financial statements prepared in accordance with the Polish Accounting Act (balance sheet, income statement, cash flow statement and statement of changes in equity) are strictly defined and companies cannot make any modifications, i.e. put additional items. In turn, in the case of the use of IFRS, companies have greater flexibility, as there is no templates of reports. Nevertheless, in practice, the analysed companies have prepared their financial statements in a form similar to the templates contained in the Act on Accounting and not have placed any additional items related directly to environmental protection.

The frequency of financial environmental disclosure in additional notes to the financial statements and in the Management Board report on the activity in the sample is similar.

Approximately $39 \%$ of the companies have not provided any financial environmental information in their annual reports (cf. Table II). A total of 90 out of 148 companies have revealed any information of this kind.

In the three sectors: energy, raw material and petroleum industry, as well as in the automotive industry, in the annual reports of all companies there can be found financial information on environmental protection. In the other analysed sectors, the percentage of companies making environmental financial disclosure is varied and ranges from $37.5 \%$ (plastics industry and construction materials industry) to $77.8 \%$ (chemical industry).

The information the most frequently disclosed in annual reports of the companies are capital expenditure on 
environmental protection initiatives (cf. Table III). They occur in two out of three reports which contain any financial environmental information. The next three most frequent issues are provisions for environmental protection costs, environmental liabilities and environmental charges. Nevertheless, the frequency of disclosure of the information compared with investment expenditure was much lower. In annual reports, the enterprises have least likely presented the data on other operating costs of environmental protection and environmental savings (respectively $19 \%$ and $13 \%$ of reports disclosing financial environmental information).

TABLE II: COMPANIES DISCLOSING FINANCIAL ENVIRONMENTAL INFORMATION IN THE ANNUAL REPORT

\begin{tabular}{|l|l|l|}
\hline \multicolumn{2}{|c}{ INFORMATION IN THE ANNUAL REPORT } \\
\hline Sector & $\begin{array}{l}\text { Number of } \\
\text { companies }\end{array}$ & $\begin{array}{l}\text { Percentage of } \\
\text { the size of the } \\
\text { sector }\end{array}$ \\
\hline Energy & 8 & 100.00 \\
\hline $\begin{array}{l}\text { Raw material and petroleum } \\
\text { industry }\end{array}$ & 7 & 100.00 \\
\hline Chemical industry & 7 & 77.78 \\
\hline Metal industry & 15 & 75.00 \\
\hline Electromechanical industry & 13 & 44.83 \\
\hline Plastics industry & 3 & 37.50 \\
\hline Construction materials industry & 6 & 37.50 \\
\hline Light industry & 4 & 66.67 \\
\hline Pharmaceutical industry & 5 & 45.45 \\
\hline Automotive industry & 5 & 100.00 \\
\hline Wood industry & 3 & 42.86 \\
\hline Food industry & 11 & 64.71 \\
\hline Other & 3 & 60.00 \\
\hline Total & 90 & 60.81 \\
\hline
\end{tabular}

Source: own calculation.

TABLE III: DISCLOSURE OF PARTICULAR ENVIRONMENTAL FINANCIAL INFORMATION

\begin{tabular}{|l|r|}
\hline Type of information & $\begin{array}{l}\text { Number of reports disclosing } \\
\text { the information }\end{array}$ \\
\hline Investment expenditure & 61 \\
\hline Ecological charges & 30 \\
\hline $\begin{array}{l}\text { Cost of allowances for greenhouse gas } \\
\text { emissions }\end{array}$ & 27 \\
\hline Fines, damages and restoration costs & 20 \\
\hline $\begin{array}{l}\text { Other operating expense for } \\
\text { environmental protection }\end{array}$ & 17 \\
\hline $\begin{array}{l}\text { Environmental liabilities (credits, } \\
\text { loans) }\end{array}$ & 33 \\
\hline $\begin{array}{l}\text { Provisions for environmental } \\
\text { protection costs }\end{array}$ & 37 \\
\hline $\begin{array}{l}\text { Subsidies for environmental } \\
\text { investments }\end{array}$ & 26 \\
\hline Environmental revenues & 25 \\
\hline Environmental savings & 12 \\
\hline Source: own calculation. &
\end{tabular}

Some explanation of this phenomenon may be the difficulty of measuring some other operating costs and savings related to environmental protection. For example, the possibility to separate operating costs of air pollution control devices depends on the technology and method of cost accounting in the enterprise. End-of-pipe devices are located in the process lines and the measurement of costs e.g. of electricity consumption is most often performed for the entire production installation, without separating the cost relating to devices reducing the emission of dust and gas.

TABLE IV: EXTENT AND QUALITY OF FINANCIAL DISCLOSURE OF ENVIRONMENTAL INFORMATION IN THE ANNUAL REPORT (DISCLOSURE INDEX VALUE)

\begin{tabular}{|l|l|l|l|}
\hline Sector & Average & $\begin{array}{l}\text { Standard } \\
\text { deviation }\end{array}$ & $\begin{array}{l}\text { Coefficient of } \\
\text { variation (\%) }\end{array}$ \\
\hline Energy & 66.67 & 11.07 & 16.58 \\
\hline $\begin{array}{l}\text { Raw material and } \\
\text { petroleum } \\
\text { industry }\end{array}$ & 49.50 & 12.90 & 26.05 \\
\hline Chemical industry & 40.00 & 25.97 & 64.92 \\
\hline Metal industry & 15.17 & 14.43 & 95.16 \\
\hline $\begin{array}{l}\text { Electromechanical } \\
\text { industry }\end{array}$ & 7.70 & 10.70 & 138.80 \\
\hline Plastics industry & 3.33 & 4.40 & 132.28 \\
\hline $\begin{array}{l}\text { Construction } \\
\text { materials industry }\end{array}$ & 3.93 & 5.90 & 149.51 \\
\hline Light industry & 11.10 & 11.17 & 100.49 \\
\hline $\begin{array}{l}\text { Pharmaceutical } \\
\text { industry }\end{array}$ & 8.77 & 12.33 & 140.32 \\
\hline $\begin{array}{l}\text { Automotive } \\
\text { industry }\end{array}$ & 19.33 & 14.20 & 73.47 \\
\hline Wood industry & 13.33 & 18.77 & 140.78 \\
\hline Food industry & 10.17 & 10.70 & 104.87 \\
\hline Other & 8.00 & 11.27 & 140.93 \\
\hline Total & 16.37 & 21.20 & 129.42 \\
\hline
\end{tabular}

Source: own calculation.

\begin{tabular}{|l|l|l|l|l|l|}
\hline \multicolumn{2}{|c|}{ TABLE V: PEARSON CORRLATION COEFFICIENTS } \\
\hline $\begin{array}{l}\text { Disclosure } \\
\text { index }\end{array}$ & $\begin{array}{l}\text { Total } \\
\text { assets }\end{array}$ & ROA & $\begin{array}{l}\text { Duration } \\
\text { of the } \\
\text { stock } \\
\text { exchange } \\
\text { listing }\end{array}$ & $\begin{array}{l}\text { Dominant } \\
\text { share of } \\
\text { foreign } \\
\text { capital }\end{array}$ \\
\hline $\begin{array}{l}\text { Disclo- } \\
\text { sure } \\
\text { index }\end{array}$ & 1.000 & 1.000 & & & \\
\hline $\begin{array}{l}\text { Total } \\
\text { assets }\end{array}$ & $0.527 *$ & 0.005 & 1.000 & & \\
\hline ROA & 0.041 & -0.016 & 0.043 & 0.104 & 1.000 \\
\hline $\begin{array}{l}\text { Dura- } \\
\text { tion of } \\
\text { the } \\
\text { stock } \\
\text { exchan } \\
\text {-ge } \\
\text { listing }\end{array}$ & -0.018 & -0.026 & -0.013 & 1.000 & \\
\hline $\begin{array}{l}\text { Domi } \\
\text {-nant } \\
\text { share } \\
\text { of } \\
\text { foreign } \\
\text { capital }\end{array}$ & & & & & \\
\hline
\end{tabular}

* significance level of 0.00001

Source: own calculation.

The level of extent and quality of financial environmental disclosure measured by the disclosure index value in the whole sample is low. The index value for all the companies is an average of only $16.37 \%$ (cf. Table IV). The average disclosure index value for individual sectors ranged from $3.33 \%$ (plastics industry) to $66.67 \%$ (energy sector). The best individual result $(80.0 \%)$ is acquired by two companies in the 
energy sector.

There is a considerable diversity of the level of quality of disclosures, in the whole sample and in most sectors, as indicated by the values of the coefficient of variation above $60 \%$.

To determine which factors influence the extent and quality of financial environmental disclosure, there has been examined the correlation between the disclosure index, total assets of the enterprises, return on assets, the duration of stock exchange listing and the share of foreign capital in the financing of companies. Pearson correlation coefficients for these variables are presented in Table V. The only variable that is statistically significantly correlated with the disclosure index are total assets. The correlation between these two variables is positive, and it is only moderate (average).

No statistically significant correlation of all the other potential factors influencing financial environmental disclosure with the disclosure index makes it pointless to use a multiple regression model in the analysis of the determinants of these disclosures.

\section{CONCLUSIONS}

The analysis has revealed that a slight majority of the surveyed companies (61\%), listed on the Polish stock exchange and classified in the sectors that are harmful to the environment, disclose financial environmental information in their annual reports, and the average level (extent and quality) of the disclosure is low.

There is a diversity of different sectors in terms of the number of companies making disclosure, as well as the level of the disclosure. There have also been noticed significant differences in the level of financial environmental disclosure within most sectors.

Compared to other sectors, energy and raw material and petroleum industry are distinguished by a higher level of disclosure, and the standard deviation is small, which means that the reports of these companies have a similar extent and quality of disclosure. The companies of these sectors can be seen as those in which environmental issues have a particular impact on their financial situation (market value) and reputation in society and perhaps therefore, they are more likely to disclose financial environmental information.

The analysed companies usually present information regarding investment expenditure for environmental protection. This can be explained on the basis of the voluntary disclosure theory: making environmental investments is seen positively in the Polish society as a manifestation of a firm commitment to reducing its environmental impact. Enterprises, therefore, are willing to reveal the 'good' news.

There is no statistically significant impact of profitability, strategic foreign investor and the period of the stock exchange listing of the company on the level of financial environmental disclosure. Nevertheless, the analysis has shown a positive moderate correlation between the disclosure level and the company size measured by total assets.

\section{REFERENCES}

[1] R. E. Freeman, Strategic Management: A Stakeholder Approach, Boston: Pitman Publishing, 1984
[2] J. Krasodomska, "Sprawozdawczość przedsiebiorstw w świetle teori legitymizacji," Studia i Prace Kolegium Zarządzania i Finansów, no. 13, pp. 39-51, 2013.

[3] K. Bewley and Y. Li, "Disclosure of environmental information by Canadian manufacturing companies: A voluntary disclosure perspective," Advances in Environmental Accounting \& Management, vol. 1, pp. 201-226, 2000.

[4] K. Hummel and C. Schlick, "The relationship between sustainability performance and sustainability disclosure - Reconciling voluntary disclosure theory nad legitimacy theory," Journal of Accounting and Public Policy, vol. 35, issue 5, pp. 455-476, September-October 2016.

[5] P. M.Clarkson, Y. Li, G. D. Richardson, and F. P. Vasvari, "Revisiting the relation between environmental performance and environmental disclosure: An empirical analysis," Accounting, Organizations and Society, vol. 33, issues 4-5, pp. 303-327, May-July 2008.

[6] T. Christopher, Y. B. S. Hutomo, and G. Monroe, "Voluntary environmental disclosure by australian listed mineral mining companies: An application of stakeholder theory," The International Journal of Accounting and Business Society, vol. 5, no. 1, pp. 42-66, August 1997.

[7] E. D'Amico, D. Coluccia, S. Fontana, and S. Solimene, "Factors influencing corporate environmental disclosure," Business Strategy and the Environment, vol. 25, issue 3, pp. 178-192, March 2016.

[8] D. Cormier, M. Magnan, and B. Van Velthoven, "Environmental Dislcosure Quality in Large German Companies: Economic Incentives, Public Pressures or Institutional Conditions?" European Accounting Review, vol. 14, no.1, pp. 3-39, January 2005.

[9] D. Cormier and M. Magnan, "Corporate environmental disclosure strategies: Determinants, costs and benefits," Journal of Accounting, Auditing \& Finance, vol. 14, no. 4, pp. 429-451, October 1999.

[10] J. M. Moneva and F. Llena, "Environmental disclosures in the annual reports of large companies in Spain," European Accounting Review, vol. 9, issue 1, pp. 7-29, 2000.

[11] N. K. Behram, "A cross-sectoral analysis of environmental disclosures in a legitimacy theory context," Journal of Management and Sustainability, vol. 5, no. 1, pp. 20-37, 2015

[12] M. H. Ullah, M. M. Hossain, and K. M. Yakub, "Environmental disclosure practices in annual report of the listed textile industries in Bangladesh," Global Journal of Management and Business Research: (D) Accounting and Auditing, vol. 14, issue 1, pp. 97-108, 2014.

[13] I. Alin, M. Victor, and M. Dumitru, "Environmental reporting within the Romanian companies," International Journal of Energy and Environment, vol. 5, issue 1, pp. 123-131, 2011.

[14] P. L. Joshi, M. S. Suwaidan, and R. Kumar, "Determinants of environmental disclosures by Indian industrial listed companies: empirical study," International Journal of Accounting and Finance, vol. 3, issue 2, pp. 109-130, 2011.

[15] M. E. Barth, M. F. McNichols, and G. P. Wilson, "Factors influencing firms' disclosures about environmental liabilities," Review of Accounting Studies, vol. 2, issue 1, pp. 35-64, March 1997.

[16] Y. Li, G. D. Richardson, and D. B. Thornton, "Corporate disclosure of environmental liability information: theory and evidence," Contemporary Accounting Research, vol. 14, issue 3, pp. 435-474, Fall 1997.

[17] K. Chang, L. Zhang, "The effects of corporate ownership structure on environmental information disclosure - empirical evidence from unbalanced panel data in heavy-pollution industries in China," WSEAS Transactions on Systems and Control, vol. 10, pp. 405-414, 2015.

[18] C. Braga, P. P. Silva, A. Santos, "Level of disclosure of environmental information in the electricity sector: An empirical study of brazil and the Iberian Peninsula," Global Journal of Management and Business Research: (B) Economics and Commerce, vol. 15, issue 9, pp. 39-53, 2015

[19] F. Carreira, A. Damiao, R. Abreu, and F. David, "Environmental disclosure - from the accounting to the report perspective," in Proc. the $16^{\text {th }}$ International Conference on Enterprise Information Systems, Lisbon, Portugal, pp. 496-501, 27-30 April, 2014.

[20] S. M. da S. Monteiro and B. Aibar-Guzman, "Determinants of environmental disclosure in the annual reports of large companies operating in Portugal," Corporate Social Responsibility and Environmental Management, vol. 17, issue 4, pp. 185-204, July-August 2010.

[21] Z. B. Ghomia and P. Leung, "An empirical analysis of the determinants of greenhouse gas voluntary disclosure in Australia," Accounting and Finance Research, vol. 2, no. 1, pp.110-127, 2013.

[22] P. Stanwick and S. Stanwick, "Corporate environmental disclosures: a longitudinal study of Japanese firms," The Journal of American Academy of Business, vol. 9, no. 1, pp. 1-7, March 2006. 
[23] R. Gamerschlag, K. Möller, and F. Verbeeten, "Determinants of voluntary CSR disclosure: empirical evidence from Germany," Review of Managerial Science, vol. 5, issue 2, pp. 233-262, July 2011.

[24] M. Macuda, Ł. Matuszak, E. Różańska, "The concept of CSR in accounting theory and practice in Poland: An empirical study," Zeszyty Teoretyczne Rachunkowości, vol. 84, pp. 115-137, 2015.

[25] E. Chojnacka and J. Wiśniewska, "Raportowanie danych CSR w Polsce," Prace Naukowe UE we Wrocławiu, no. 436, pp.55-63, 2016.

[26] E. I. Szczepankiewicz and P. Mućko, "CSR Reporting practices of polish energy and mining companies," Sustainability, vol. 8, issue 2, pp. $1-17,2016$

[27] M. Ciechan-Kujawa, "Użyteczność raportów CSR w ocenie stopnia zaangażowania przedsiębiorstw w odpowiedzialność społeczną," Prace Naukowe UE we Wrocławiu, no. 311, pp. 32-44, 2013.

[28] A. Szadziewska, "Environmental reporting by large companies in Poland," Zeszyty Teoretyczne Rachunkowości, no. 68, pp. 97-119, 2012.

[29] A. Paszkiewicz and A. Szadziewska, "Raportowanie ekologicznych aspektów działalności w przedsiębiorstwach energetycznych chemicznych," Zeszyty Naukowe Uniwersytetu Szczecińskiego, no.
625, Finanse, Rynki Finansowe, Ubezpieczenia, no. 32, pp. 295-311, 2011.

[30] A. Balicka, "Wskaźniki środowiskowe w zewnętrznej sprawozdawdzości środowiskowej," Prace Naukowe UE we Wroctawiu, no. 388, pp. 212-220, 2015.

[31] S. B. Hughes, A. Anderson, and S. Golden, "Corporate environmental disclosures: are they useful in determining environmenta performance?" Journal of Accounting and Public Policy, vol.20, issue 3, pp. 217-240, Autumn 2001.

[32] J. Krasodomska, "CSR disclosures in the banking industry. Empirical evidence from Poland," Social Responsibility Journal, vol. 11, issue 3, pp. 406-423, 2015

Justyna Dyduch is an assistant professor at the Department of Economics, Finance and Environmental Management, Faculty of Management, AGH University of Science and Technology, Cracow, Poland. Her research interests include financial environmental reporting, environmental finance, corporate finance and corporate bond market. 